\title{
Michelangelo Pistoletto's Community of Limits
}

Gianmarco Visconti

\begin{abstract}
This essay takes a look at the career of Italian artist Michelangelo Pistoletto during the 1960s, seeking to make connections between his work, Italy's shifting social atmosphere and the impetus of youth counterculture at the time. Through the formal analysis of Pistoletto's paintings, sculptures, and performances, the paper culminates in a discussion of the meaning of community and its value in an industrialized world.
\end{abstract}

The 1960s in Italy were coloured by a general discontentment with the institutional "framing" of the art world, in which painting was held above all other mediums. In the United States this discourse was carried out through the development of avant-garde movements such as Pop Art, Minimalism, and Conceptual Art where, rather than just changing the way art objects were made, many artists opted to change the context in which their works were seen or experienced. ${ }^{1}$ They brought their abstractions to the street, anywhere outside of the institutional realm of art, and they searched for ways to make art objects vulnerable or even secondary to the space in which they were found. ${ }^{2}$ Since the 1920 s the avant-garde had been mixing its artistic radicalism with politics. In particular, the Surrealists were fond of using Marxist rhetoric to fortify their own goals of freeing the mind from the effects of preexisting societal structures, which hindered its expression. This need for "communal free expression" found itself echoed in the 1960s by various artistic communities across Europe. This time it was the youth counterculture that found itself at the centre of this discourse, frustrated with the idea of "capitalist freedoms." Thus, this questioning of governmental authority pushed certain artists to attempt the dissolution of artistic sources of authority, which often involved a process of dematerialization and the elevation of concept over the physical object. ${ }^{3}$ Italian artists were similarly grasped by feelings of disillusionment, which is often used to explain the creation of the Arte Povera movement, whose artists were attempting to renegotiate the links between art and life and the art object. The movement itself and the artists belonging to it are difficult to formally define; however, the works of Arte Povera are unified by their intention to conceive of a new beginning for art. Arte Povera required a laboratorial or speculative approach in the sense that its artists felt free to adjust and exaggerate their approaches to various forms and mediums. The goal was to create without any preconceptions in mind as a way to advance forward toward newer and better understandings of art. ${ }^{4}$ Michelangelo Pistoletto is one particular Arte Povera artist that really seemed to take this idea of a speculative art to heart: throughout his career he moved between various mediums, going from painting to sculpture to installation, and with each attempt he took a new angle on what forms and what materials could be appropriate for artistic exploration. ${ }^{5}$ Yet, Pistoletto's way of using quotidian materials in his work to encroach on more traditionally valued art materials not only spoke to the disgruntled youths of his time, and their opposition to institutionalized structure, but it also tapped into a uniquely Italian sensibility.

\footnotetext{
${ }^{1}$ Richard Flood and Frances Morris, "Introduction: Zero to Infinity," in Zero to Infinity: Arte Povera 1962-1972, ed. Richard Flood (Minneapolis: Walker Art Center, 2001), 15.

${ }^{2}$ David Hopkins, Oxford History of Art: After Modern Art 1945-2000 (Oxford: Oxford University Press, 2000$), 161$.

${ }^{3}$ Hopkins, Oxford History of Art: After Modern Art 1945-2000, 161-165.

${ }^{4}$ Flood and Morris, "Introduction: Zero to Infinity," 15.

${ }^{5}$ Ibid., 18.
} 
Arte Povera was defined by the critic Germano Celant in 1967, although the artists themselves that he identified as part of this group were never formally unified. The idea that Arte Povera revolved around the use of meagre or common materials is too narrow: Celant used the word "poor" in the sense of something having been stripped down and simplified to its basic elements. In fact, he was drawing upon Jerzy Grotowski's concept of "poor theatre," in which performances were based solely on body language and the actor's own ability to express himself physically. The stage was also taken out of the equation so as to place the actors and the audience on the same level, establishing a direct connection between these two entities. ${ }^{6}$ Celant also used the metaphor of guerilla war to explain Arte Povera: he saw each artist as a solitary unit, paving the way for new kinds of art and working against convention simultaneously. Yet he also praised the way the movement cultivated an image of the artist as a person who "mixes himself with the environment, camouflages himself... enlarges the threshold of things... [drawing] from the the substance of the natural event." Therefore, for Celant, the Arte Povera artist was someone who was undermining and working against convention but whose protests did not necessarily come from direct confrontation or activism. Any transgressive aspects of the artist's work were secondary: it was an effect caused by his desire to create from the place of his everyday life. ${ }^{8}$ This went against artistic convention because art, as an institution, was known for maintaining distance from the everyday; however, Arte Povera was still working within the system, attempting to foster communication from within.

Celant did not consider the wave of student revolts in Italy as an influencing factor on Arte Povera's trajectory. From 1967-68, Italy saw a wave of student protests overtake the political landscape. In a movement that started in Turin and would eventually hit Bologna, Italian students began to occupy their own universities, their discontentment having reached a point of explosion. They held assemblies, organized their own curriculums on subjects that interested them, and, in the Turin case, drew up a manifesto to justify their occupation. As these students fought with the police, some campuses were repeatedly taken and retaken. Ultimately this was a violent reaction to the hard-line educational system in Italy: students felt they were being consciously detached from society and from one another. The majority of universities were state funded institutions that were effectively run by its officials. The professors did not truly consider themselves educators, they were more interested in the running of their medical and law practices, and in the publishing of their theses. The students, thus, became cursory figures in their own educational system. ${ }^{9}$ The result was a sense of disintegration as students felt themselves stricken by anomie. This conflict reached its height in 1969 and, while it was much more aggressively political than the discourse typically found in the works of Arte Povera, we can see aspects of it did factor into Pistoletto's practices. There is a shared feeling of disillusionment between Pistoletto and the student protestors: both were trying to process how they fit into a rigid societal structure and were searching for an intellectual space in which to breathe freely. ${ }^{10}$

Already in the late 1950s, Pistoletto found his hometown of Turin being rapidly changed by the impetus of the automobile industry and the influx of workers from Southern Italy. This

\footnotetext{
${ }^{6}$ Christiane Meyer-Stoll, "Che fare? What Is to Be Done?" in Che fare? Arte Povera - The Historic Years, ed. by Friedemann Malsch et al. (Heidelberg: Kehrer, 2010), 12.

${ }^{7}$ Hopkins, Oxford History of Art: After Modern Art 1945-2000, 170.

${ }^{8}$ Meyer-Stoll, "Che fare? What Is to Be Done?" 13.

${ }^{9}$ Federico Mancini, "The Italian Student Movement," AAUP Bulletin 54:4 (1968): 427-429.

${ }^{10}$ Meyer-Stoll, "Che fare? What Is to Be Done?" 14.
} 
development is notable because the social interactions within Pistoletto's own community were becoming more centred on money and consumerism. At the time, Pistoletto worked mainly as a portraitist and his work at this time remains focused around notions of incompleteness and fragmentation. He begun in 1955 a series of self-portraits, which seem to aggressively deny the idea that one's essence, the artist's essence, can be captured and held within a single image. In a self-portrait from 1956 (fig. 1), Pistoletto's face has been rendered so loosely that it appears to dissolve upon the surface of the canvas in a flurry of coloured brushstrokes. ${ }^{11}$ In others, such as one from 1959 (fig. 2), Pistoletto appears as a black silhouette against a solid background, a silvery wash of paint, and his figure has been caged in by a series of thin rope which have been tied vertically over the canvas, further barring the viewer's access to the contents of the image. Overall, were they not labelled as self-portraits, we would not be able to identify them as the artist's own representation of himself: in fact, they would read as anonymous male figures. One interpretation is that Pistoletto was projecting the growing sense of estrangement between people in his community. Another is that he was expressing his own fears about being an artist in the modern age. This wavering between internal and external concerns would end up being a common theme in Pistoletto's work. We may see this encapsulated in "La folla" (The Crowd), a work from 1959 (fig. 3), where a whole crowd of people has replaced the singular standing figure. Considering the figures take up the entirety of the canvas, collapsing the break between the foreground and the background, they make up a unified whole, and yet they are no more recognizable than Pistoletto's self-portraits. ${ }^{12}$

Moving into the 1960s, Pistoletto dedicates his time to exploring the limits between the foreground and the background in his paintings, placing standing objects against empty backdrops as a way to expand upon this relationship. This led Pistoletto to create his famous mirror paintings, which he would continue to create throughout his whole career even while pursuing other projects in other mediums. Once again, Pistoletto simultaneously illustrates notions of anonymity and community: the act of painting a lone figure against the ever-changing, unstable backdrop of a highly reflective surface, which effectively ruptures any sense of the painting as an alternate reality, recalls the human figure's replaceability in a world where images are easily reproducible. Pistoletto's figures are self-contained entities floating in a space over which they have no control and, seeing as their limits are clearly defined for us, we know they cannot reach out. Conversely, we are also unable to reach them. Therefore, on one hand, these paintings reflect the ephemeral quality of modern social interactions: the immediacy with which the mirror can capture the present moment, reflecting everything which comes before it, parallels the furtive glances we make as we go throughout our days. However, Pistoletto's mirror paintings do, in fact, express something about community and its permanent bonds. As we stand before them, we bear witness to the forging of new communal ties, and even become a participant in this staging. Even in a painting like "Donna seduta di spalle" (Seated Woman from Behind) from 1963 (fig. 4), where the main figure is facing away from the viewer, thus deflecting the viewer, a point of contact is made. Clearly, on one hand, the figure's posture is a denial of interaction and puts the viewer in the role of a stranger; however, the reflective surface adds another layer to this dynamic. When we stand in front of this work the figure appears to be

\footnotetext{
${ }^{11}$ Angela Vettese, "From the Early Paintings to the First Reflective Surfaces," in Michelangelo Pistoletto: From One to Many, 1956-1974 ed. by Carlos Basualdo (Philadelphia: Philadelphia Museum of Art, 2010): 31.

${ }^{12}$ Carlos Basualdo, "Michelangelo Pistoletto: From One to Many, 1956-1974," in Michelangelo Pistoletto: From One to Many, 1956-1974 ed. by Carlos Basualdo (Philadelphia: Philadelphia Museum of Art, 2010): 4-5.
} 
sitting in between ourselves and our reflection so, in fact, the painted figure is face to face with our reflection but not with us. The figure's space becomes our space and vice versa. ${ }^{13}$ Therefore, that initial awkward encounter that the work provokes is converted into a familiar one. All in all, the mirror paintings are a play on what it means to be socially engaged: the viewer experiences one kind of interaction, and the mirror reflects back a differing situation. Pistoletto's early paintings suggest the artist greatly internalized the crises and preoccupations of Post-war Italy and the new industrialized world it brought. It is easy to link his later mirror paintings with this narrative of disillusionment, yet they establish various themes that will become very important to Pistoletto. He sought a road somewhere between the dichotomy of abstraction and naturalism, which were often two opposing forces in Italian art. ${ }^{14}$ In more broad terms, Pistoletto's work would centre itself on the interactions between passive and active elements. ${ }^{15}$ Within this dynamic lies the crux of Pistoletto's views on community: "I proceeded intuitively with the intention of joining up the two images - the one offered by the mirror and the one that I produced myself. The result was the superimposition of the two pictures; painting is superimposed on the picture of reality and becomes part of it." ${ }^{16}$ The mirror paintings are designed to illustrate points of contact between themselves and the audience, while still allowing the viewer to take a step away from the situation to get a better understanding of the relationships in play.

Between 1965 and 1966, Pistoletto commenced a new project, the "Oggetti in meno" (Minus Objects), which consisted of almost 30 different multi-media sculptures that were all exhibited in Pistoletto's studio in Turin, which was inside his home. ${ }^{17}$ In many ways "Oggetti in meno" was a reaction against the recent publicity Pistoletto had garnered for his earlier mirror paintings. Confronted by demands to make replicas of these paintings for private collectors, Pistoletto decided to shrink back from the market and to focus on a different project completely. This might make the gesture of exhibiting in his own studio seem self-involved but it was more about introducing the artist's studio as a place for experimentation. When this series was installed, there already existed a certain concept of what an artist's studio should be. Images of the artist's workspace had become a part of popular culture as a representation of his or her space for contemplation. It was the place of creation where the artist's concepts and the manual labour needed to realize them met. Yet Pistoletto found ways to reject this notion of the artist as an inspired outsider who leaves a small piece of himself in everything he or she makes. When Paolo Bressano, a photographer and a friend of Pistoletto, went to document the "Oggetti in meno" in the artist's studio, he excluded him from the photographs. That way, all one sees is a space filled with seemingly random objects covering the walls and floors. ${ }^{18}$ For Pistoletto the purpose of making the "Oggetti in meno" was very much about erasing and denying the public need to identify the artist in his work through personal style. There was only one rule guiding Pistoletto's construction of each object: in his own words, he had to use "the most available material, the most available idea." 19 Therefore, the phrase "in meno" in the way Pistoletto used it meant

\footnotetext{
${ }^{13}$ Basualdo, "Michelangelo Pistoletto: From One to Many, 1956-1974," 6-7.

${ }^{14}$ Vettese, "From the Early Paintings to the First Reflective Surfaces," 37.

15 Ibid., 38.

${ }^{16}$ Robin Hemmer and Christiane Meyer-Stoll, "Michelangelo Pistoletto: Autoritratto di schiena, 1968," in Che fare? Arte Povera - The Historic Years, ed. by Friedemann Malsch et al. (Heidelberg: Kehrer, 2010), 262.

${ }^{17}$ Steven Petersen, "Michelangelo Pistoletto: Against Imperatives," Sculpture 30:6 (2011): 25.

${ }^{18}$ Gabriele Guercio, "A Community of the Non-All," in Michelangelo Pistoletto: From One to Many, 1956-1974 ed. by Carlos Basualdo (Philadelphia: Philadelphia Museum of Art, 2010): 109.

${ }^{19}$ Petersen, "Michelangelo Pistoletto: Against Imperatives," 22-23.
} 
deficiency, as if he was short of what he really needed. None of the objects could be made into a cohesive whole so as to comment on the singular style of the individual artist. In fact, Pistoletto hoped that together the sculptures would appear to have been made by "20 different artists at the same time." 20 When we compare works such as "Ti amo" (I Love You, 1965-66) and "Colonne di cemento" (Concrete Columns, 1965-66), both part of the same series (fig. 5 and 6), it is easy to see how quickly all coherence is drained from the exhibition. Each piece reinforces its own borders, conceptually and materially: one is painted, the other sculpted and assembled, one recalls Pop Art, the other Minimalism etc. ${ }^{21}$ In 1966, Pistoletto had this to say of his assemblages: "[they] are not constructions of fabrications of new ideas, any more than they are objects which represent me... Rather, they are objects through whose agency I free myself from something - not constructions, then, but liberations. I do not consider them more but less, not pluses but minuses." 22 The viewer is free to regard the "Oggetti" as existing in an open-ended space and not in the artist's territory. We are encouraged to take notice of the lack of unity between the objects: the conscious disjointed nature of the pieces prevents us from even considering them as a collection of related things, let alone a unified whole. ${ }^{23}$ Pistoletto's ideas about community conveyed through the "Oggetti in meno" instead revolve around the idea of "inconsistent multiplicity." 24 This not only refers to the fact that the works are a blending of various incongruous materials that have been freely manipulated but also to the opening up of the artist's studio to the public. Both of these gestures removed the museum or the gallery as an intermediary figure and allow for the artist's ideas to be diffused into the public. Furthermore, the works themselves are conceptually released from the ownership of any one individual person or institution or principle. The public was free to make of the "Oggetti" as they willed. In short, community is expressed through the "Oggetti in meno," not through a fused totality, but rather through the notion of incompleteness. The ties which link the objects is their proximity to one another, which also means it is the shared gap between them which connects them. ${ }^{25}$ Community is defined through its limitations: although the objects are superficially unable to relate to one another, they are still accessible.

In the late 1960s, Pistoletto began creating his rag sculptures. At the time, these sculptures were taken to be the quintessential argument of the Arte Povera movement. On one hand, they do speak to a certain opposition to representationalism and highly manipulated materials. However, the rag sculptures still share some thematic elements with the "Oggetti in meno" in that they also evoke a sense of community expressed through the setting up of boundaries. The rags were first incorporated into Pistoletto's performances with Lo Zoo (The Zoo), a group he founded and collaborated with from 1968 in order to conduct theatrical experiments. ${ }^{26}$ When Lo Zoo arrived in Amalfi for the exhibition Arte Povera + Azioni Povere in 1968, Pistoletto installed a few rag sculptures as a way to frame the space in which his group would be performing: "When I arrived in Amalfi I had this bundle of rags, and I thought I could make something with them... All the space was occupied already, except for one small area, which... contained the remains of Roman

\footnotetext{
${ }^{20}$ Petersen, "Michelangelo Pistoletto: Against Imperatives," 23.

${ }^{21}$ Guercio, "A Community of the Non-All," 113.

${ }^{22}$ Ibid., 115.

${ }^{23}$ Ibid., 109.

${ }^{24}$ Ibid., 110.

${ }^{25}$ Ibid., 110.

${ }^{26}$ Claire Gilman, "Pistoletto's Object Theater," in Michelangelo Pistoletto: From One to Many, 1956-1974 ed. by Carlos Basualdo (Philadelphia: Philadelphia Museum of Art, 2010): 81.
} 
ruins... With my rags I could decorate the Roman objects, hang them on the inside, and in this way create my own little set design. I had arranged my own little theater; the Roman ruins became just like the rags." 27 This set up a specific type of interrelationship between the actions of Lo Zoo and the statues: the rags seemed to put a limit on the movements of the performers, interrupting the action to a certain degree, while the rags themselves seemed to be activated, or given meaning, by the actions of the performers. ${ }^{28}$

Pistoletto's “Orchestra di stracci” (Orchestra of Rags, 1968) was a less spontaneous rag installation (fig. 7) used to mark the space in which Lo Zoo would be doing a four-hour improvisational performance in Turin. It consisted of a series of assemblages, made up of steaming teakettles enclosed by a ring of rags and covered with a panel of glass. So, the steam would rise from the kettles only to be absorbed by the surrounding wall of cloth. This perpetual motion captures the tension between freedom and control with which Pistoletto liked to experiment: "I think the 'orchestra of rags' was a very good example to demonstrate what [Lo Zoo's] performances were like... Boilers that produced steam, wet rags, that particular smell of humidity, just like in a laundry room, and the whistling sound of the boilers as music, are all reasons why we called it an "orchestra.", 29 The kettles represent this chaotic, creative process, which hints at its own climax, yet the rags don't allow any point of bursting to be reached, as they provide the work with its limitations. Thus, through the interaction of its materials, the piece is able to continuously exist in the present. ${ }^{30}$ Other examples of Pistoletto's rag sculptures include "Muretto di stracci" (Wall of Rags, 1968) and "Venere degli stracci" (Venus of the Rags, 1967), which both accomplish similar goals. In "Muretto di stracci" the rags have been shaped into bricks and then stacked upon one another, while in "Venere degli stracci" (fig. 8) they have been allowed to sit in a disorderly pile in contrast to a classical female nude statue. Yet, in both works, neither element dominates over the other: the tattered, unstable, form of the rag itself is placed on equal footing with highly worked sculptural and architectural forms. That said, "Venere degli stracci" is Pistoletto's rag sculpture that most expresses a sense of community: first of all the image of the female statue leaning into a pile of rags recalls the manual labour which made the statue possible. The rag is also a subtraction from the whole: it is a tool of the worker and it is the clothes that he or she wears. It is also anonymous in that we cannot know who it belongs to. The only way we can know of the community that the piles of rags represent is through the object which anchors them: in this case the statue. ${ }^{31}$ In this manner, this work stages a point of contact between two sections of society: the art world and everyday life. On the other hand, the rags have been absorbed into the realm of art and thus aestheticized by this gesture, finding themselves stripped of their status as an everyday object. This does not seem consistent with Pistoletto's own views of community, but could be a comment on the times in which the artist was working, in regards to the youth revolts. By forcing an artefact from the canon of Italian art to confront a multitude of everyday, inconsequential objects associated with hard labour, Pistoletto recalls the spirit of these student protests and their attempted break with the

\footnotetext{
${ }^{27}$ Gilman, "Pistoletto's Object Theater," 91-92.

${ }^{28}$ Ibid., 92.

${ }^{29}$ Michelangelo Pistoletto, "Michelangelo Pistoletto in conversation," in Azioni Materiali ed. by Silvia Eiblmayr (Köln: Buchhandlung Walther König, 1999), 37.

${ }^{30}$ Gilman, "Pistoletto's Object Theater," 94.

${ }^{31}$ Robin Hemmer and Christiane Meyer-Stoll, "Michelangelo Pistoletto: Muro di stracci, 1968," in Che fare? Arte Povera - The Historic Years, ed. by Friedemann Malsch et al. (Heidelberg: Kehrer, 2010), 264.
} 
status quo. ${ }^{32}$ However, in this case, "Muretto di stracci" makes the strongest connection with the revolts, imitating the kinds of barricades rioters used to express their dissent and discontentment. ${ }^{33}$ Overall, no matter how one decides to interpret the rag sculptures, their significance is always defined by human involvement and the internal relationships they evoke.

In summary, Michelangelo Pistoletto's work may be characterized by the tension between singularity and anonymity. ${ }^{34} \mathrm{He}$ was an artist who constantly grew into the use of different mediums during a time when his community was largely in a state of unrest. His shifting identity as an artist was at once unique to his experience but also representative of what everyone around him was going through as well. He was a guerilla artist, clearing away his own path, yet he always kept a handle on his environment. He demonstrated his understanding of community as a concept by delineating limits because this gave him a vantage point from which to view himself and those around him.

\section{Bibliography}

Basualdo, Carlos, ed. Michelangelo Pistoletto: From One to Many. Philadelphia: Philadelphia Museum of Art, 2010.

Malsch, Friedemann, Christiane Meyer-Stoll, and Valentina Pero, ed. Che fare? Arte Povera The Historic Years. Heidelberg: Kehrer, 2010.

Flood, Richard, and Frances Morris, ed. Zero to Infinity: Arte Povera, 1962-1972. Minneapolis: Walker Art Center, 2001.

Eiblymayr, Silvia, ed. Azioni Materiali. Köln: Buchhandlung Walther König, 1999.

Hopkins, David. Oxford History of Art: After Modern Art 1945-2000. Oxford: Oxford University Press, 2000.

Petersen, Steven. “Michelangelo Pistoletto: Against Imperatives.” Sculpture 30:6 (2011): 20-27.

Gilman, Claire. "Pistoletto’s Staged Subjects.” October 124 (2008): 53-74.

Arnadaut, Didier. "Michelangelo Pistoletto: Working for the Third Paradise." Art Press 382 (2011): 48-50.

Mancini, Federico. “The Italian Student Movement.” AAUP Bulletin 54:4 (1968): 427-432.

Nancy, Jean-Luc. "Literary Communism." in Nancy, The Inoperative Community, translated by Peter Connor, 71-81. Minneapolis: University of Minnesota Press, 1991.

\footnotetext{
${ }^{32}$ Petersen, "Michelangelo Pistoletto: Against Imperatives," 25.

${ }^{33}$ Gilman, "Pistoletto's Object Theater," 96.

${ }^{34}$ Basualdo, "Michelangleo Pistoletto: From One to Many, 1956-1974," 1.
} 


\section{Appendix}

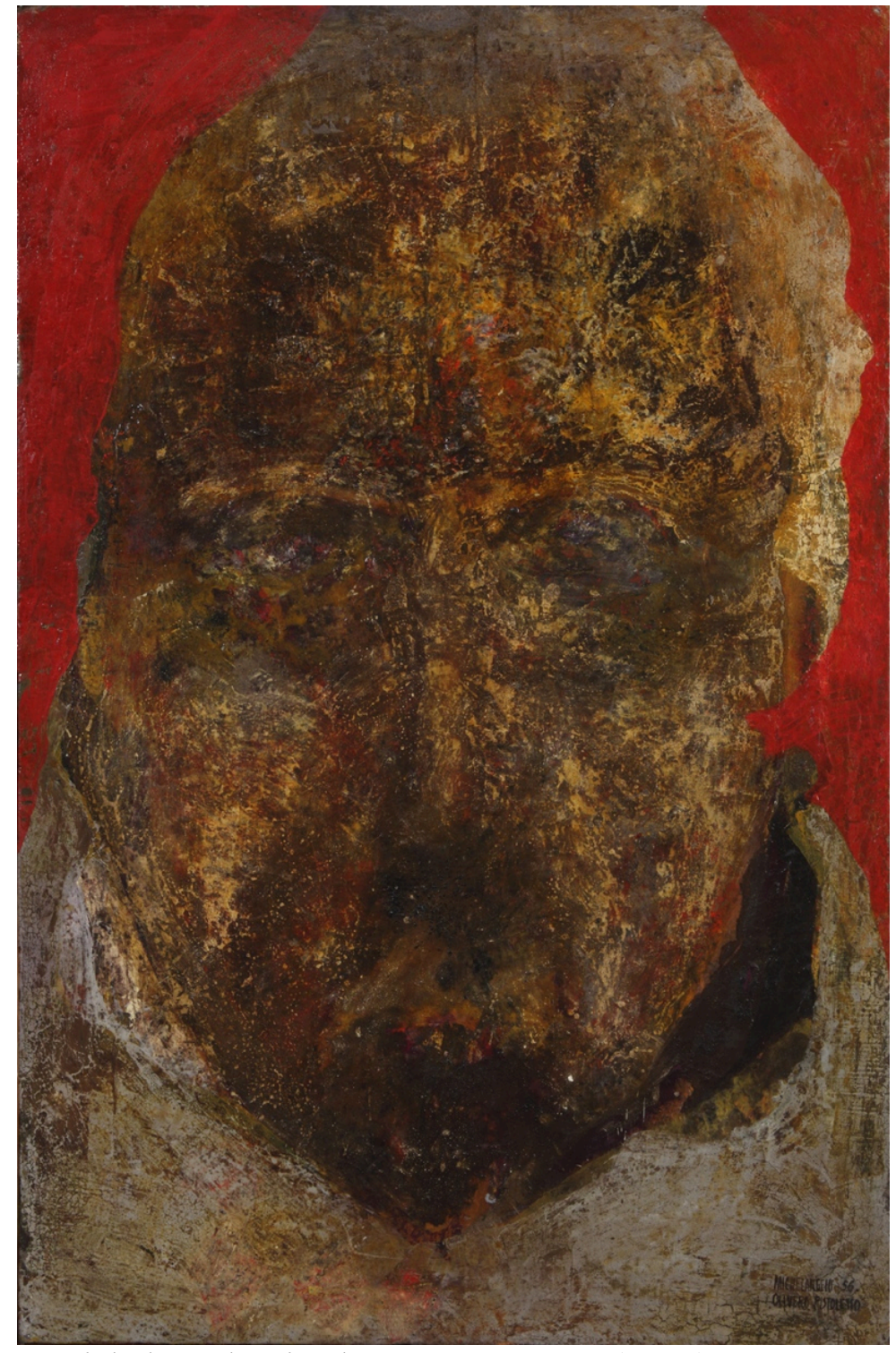

1. Michelangelo Pistoletto, Autoritratto (1956). Source: Universalmuseum Joanneum. 


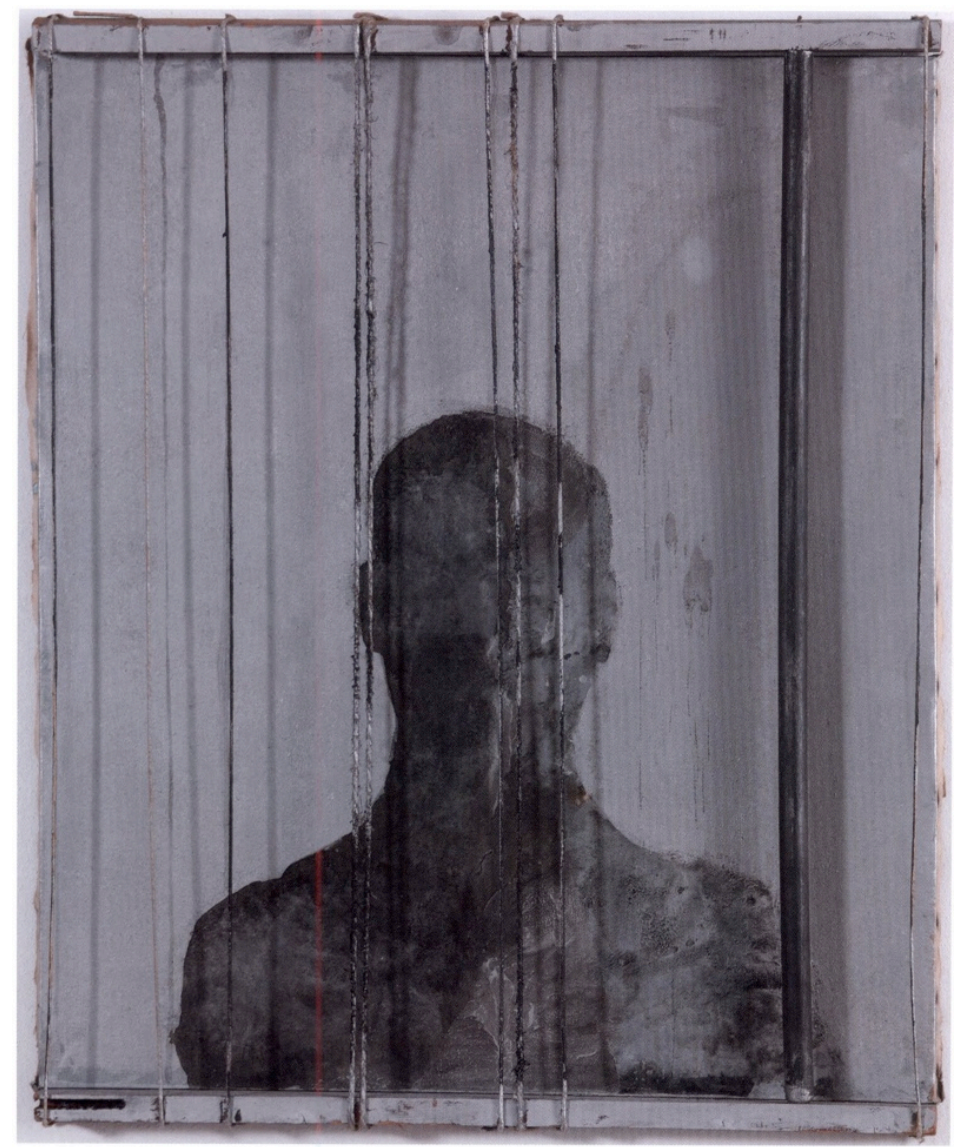

2. Michelangelo Pistoletto, Esperimento (1959). Source: Carlos Basualdo, ed., Michelangelo Pistoletto: From One to Many, 1956-1974. 


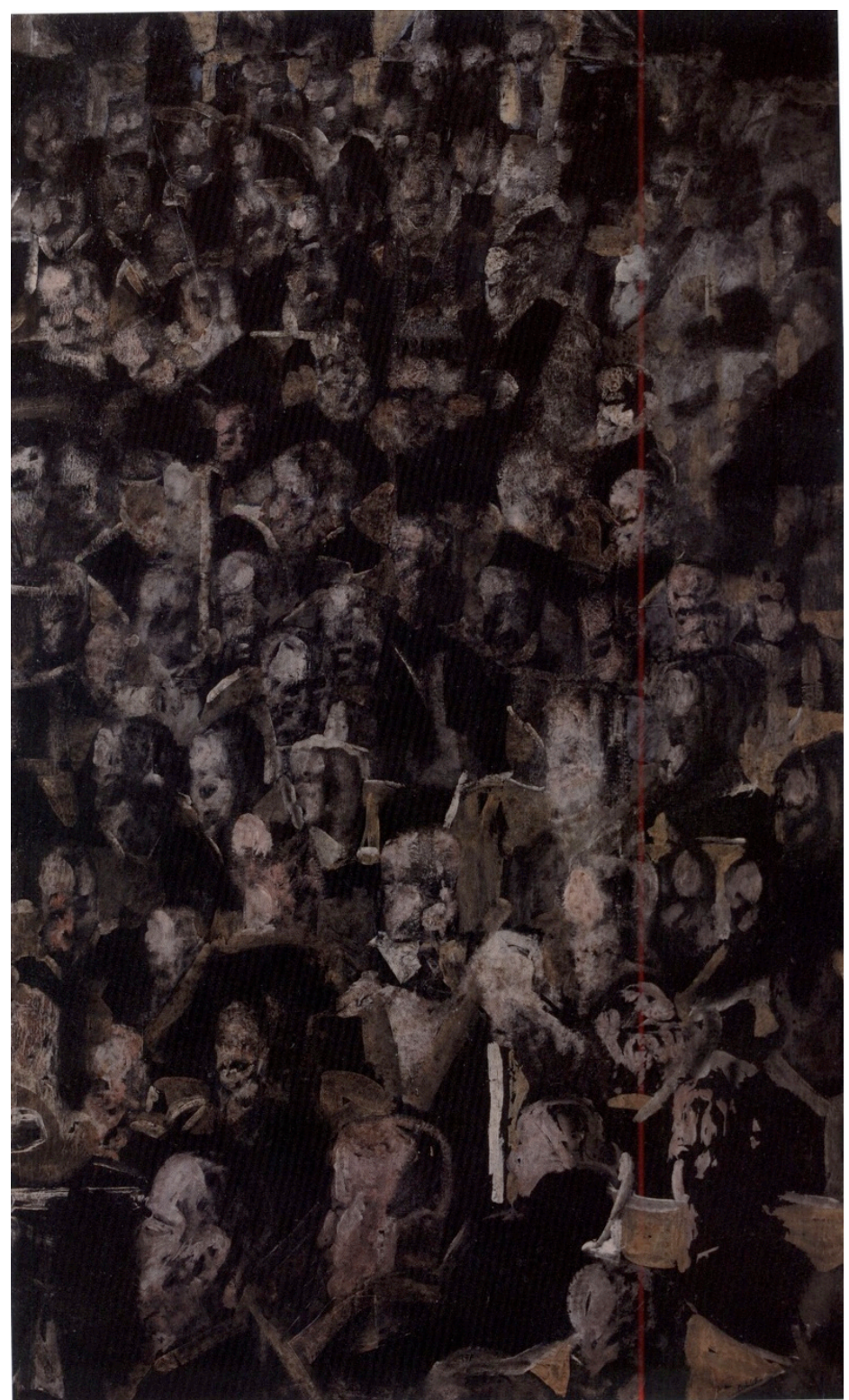

3. Michelangelo Pistoletto, La folla (1959). Source: Carlos Basualdo, ed., Michelangelo Pistoletto: From One to Many, 1956-1974. 


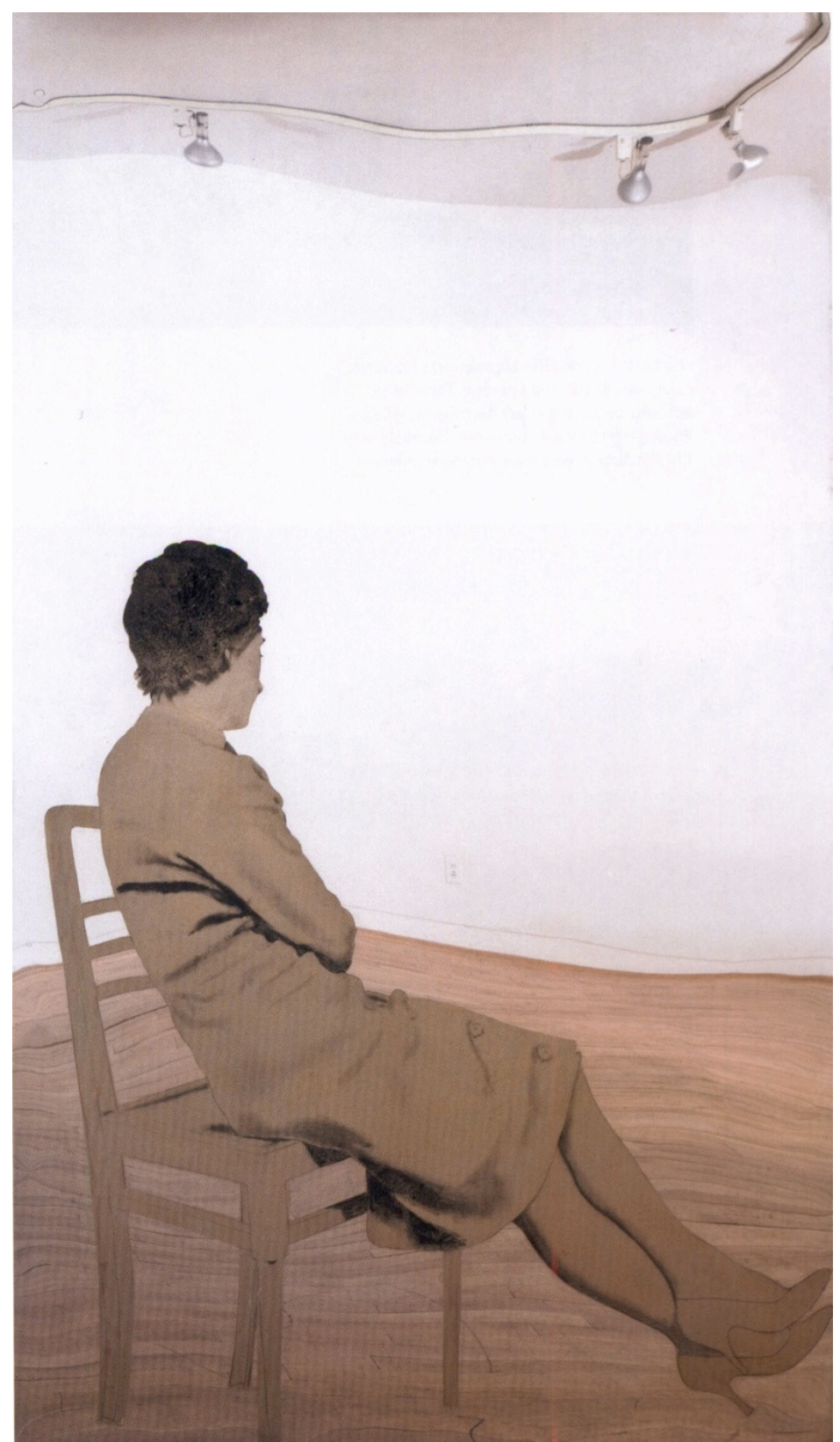

4. Michelangleo Pistoletto, Donna seduta di spalle (1963). Source: Carlos Basualdo, ed., Michelangelo Pistoletto: From One to Many, 1956-1974. 


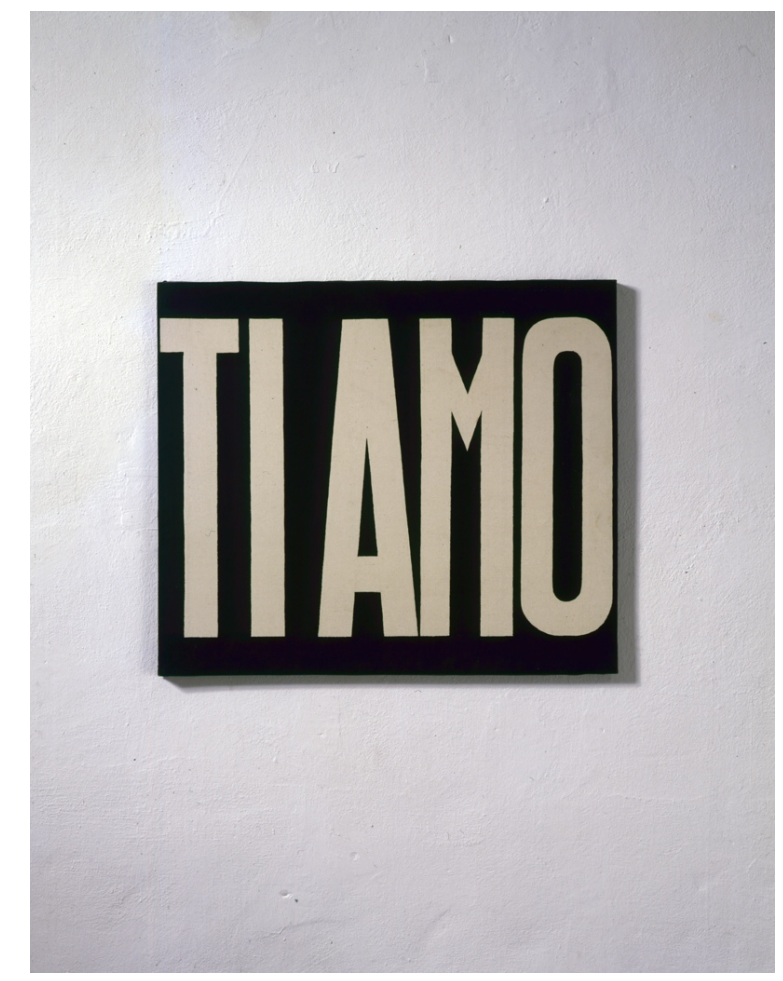

5. Michelangelo Pistoletto, Ti amo (1965-66). Source: Universalmuseum Joanneum.

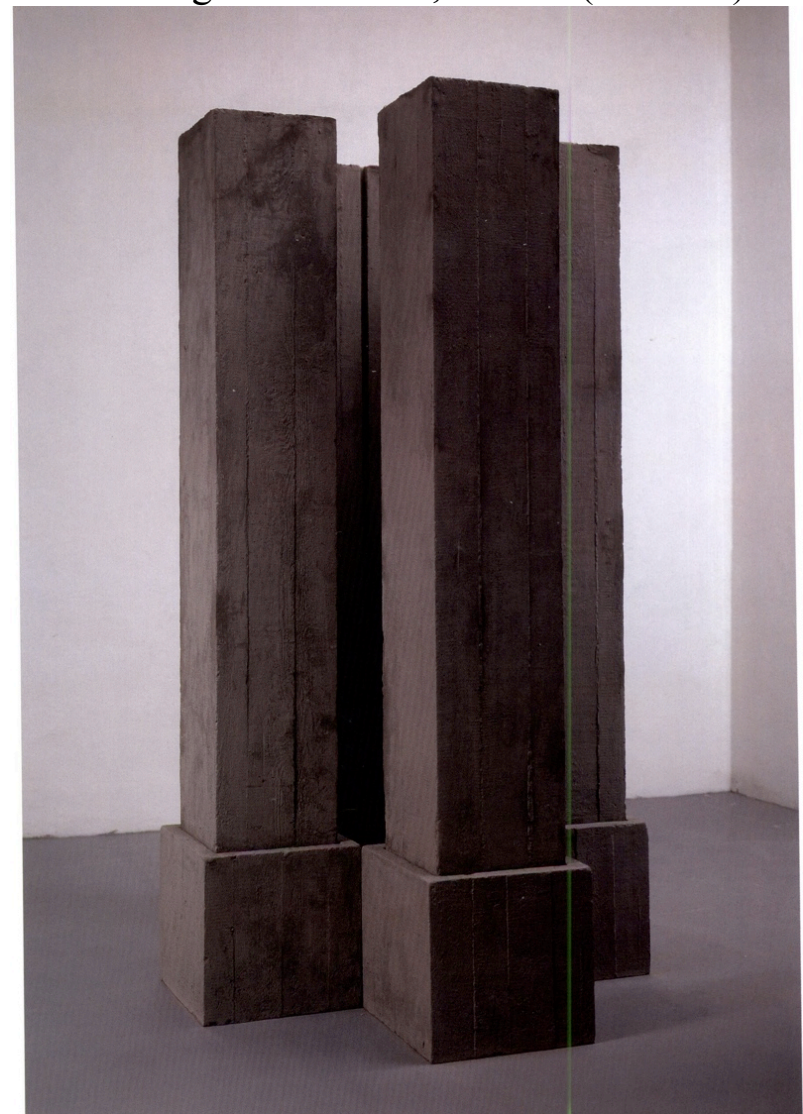

6. Michelangelo Pistoletto, Colonne di cemento (1966). Source: Carlos Basualdo, ed., Michelangelo Pistoletto: From One to Many, 1956-1974. 


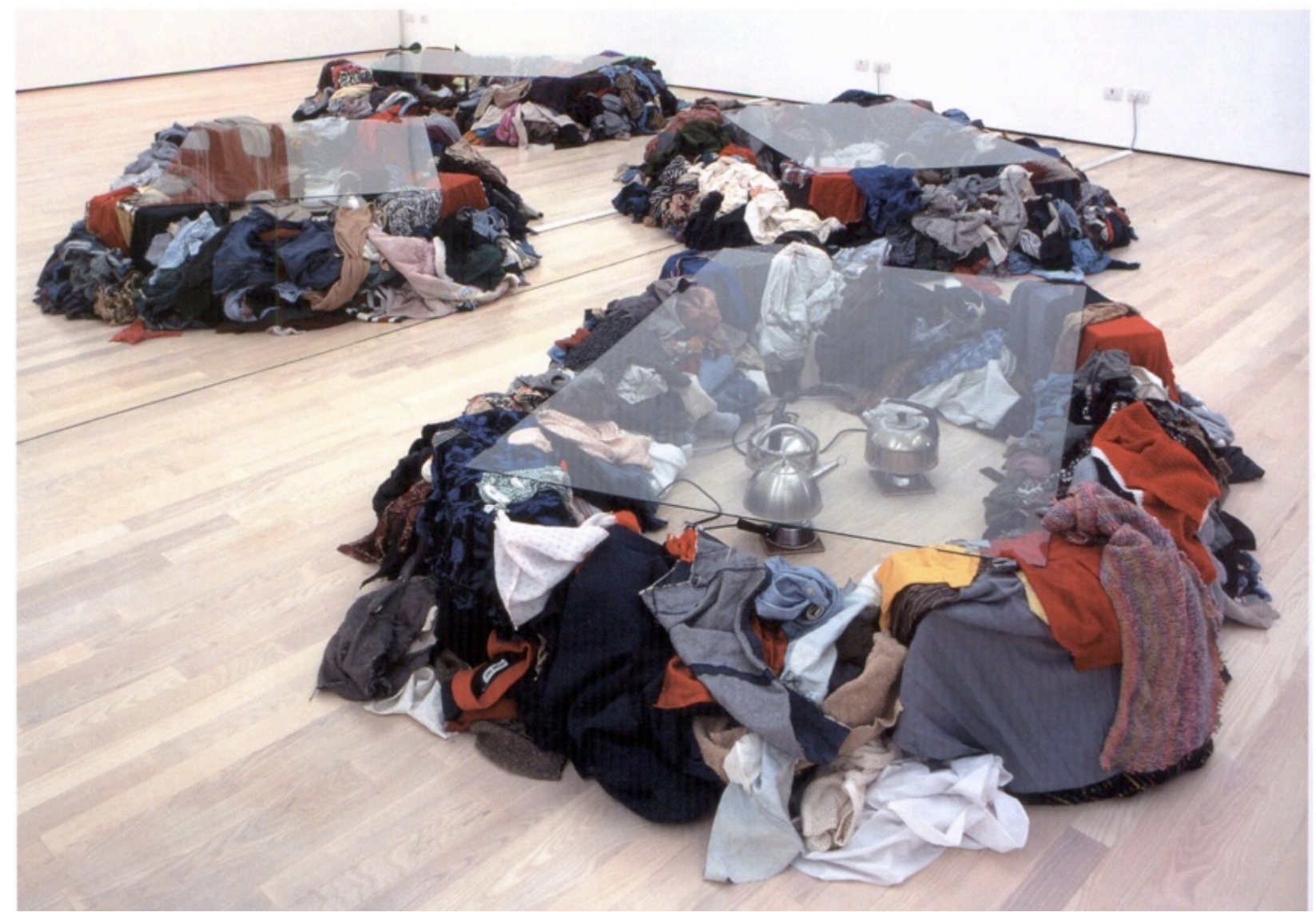

7. Michelangelo Pistoletto, Orchestra di stracci (1968). Source: Carlos Basualdo, ed., Michelangelo Pistoletto: From One to Many, 1956-1974. 


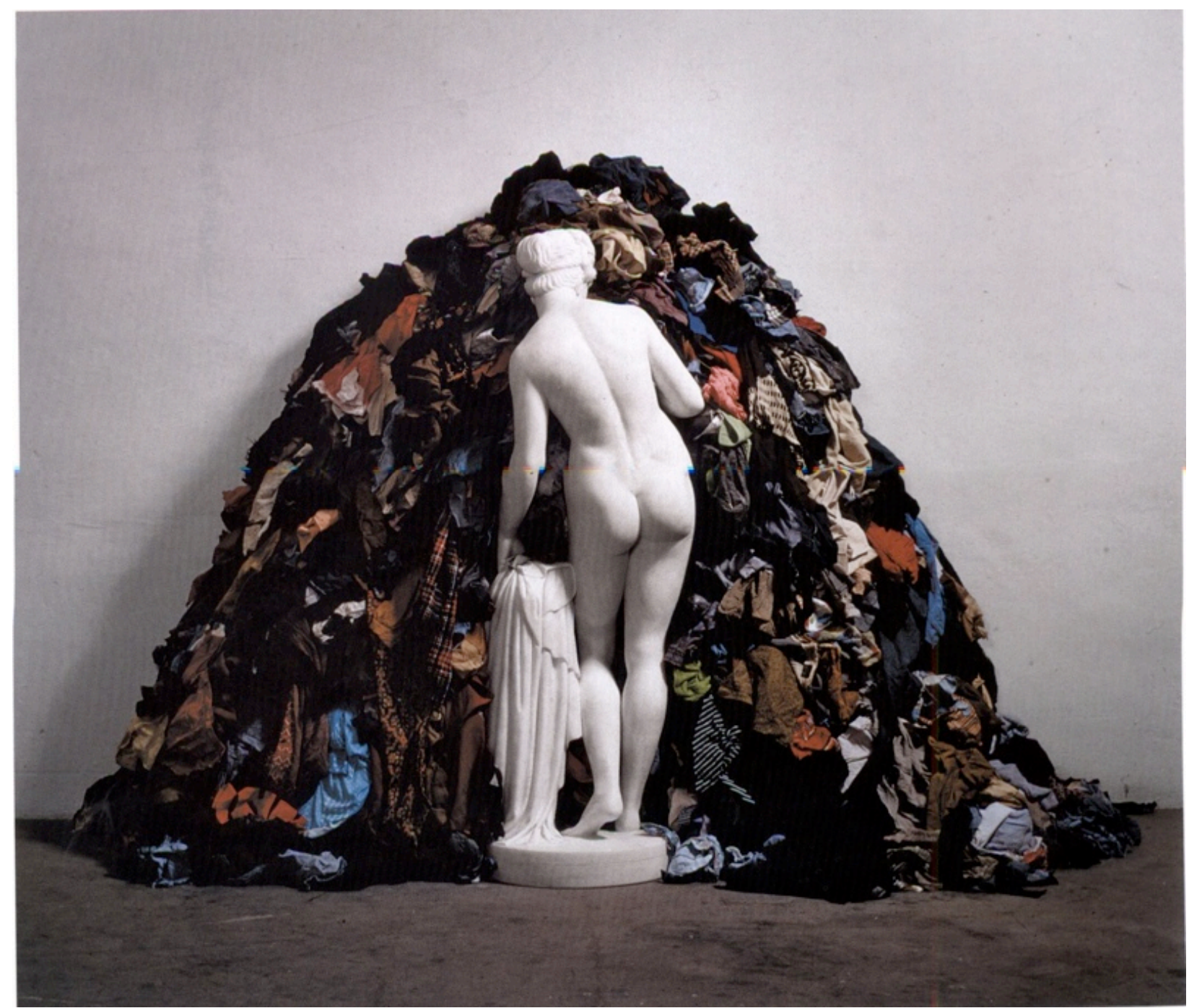

8. Michelangelo Pistoletto, Venere degli stracci (1967). Source: Carlos Basualdo, ed., Michelangelo Pistoletto: From One to Many, 1956-1974. 